\title{
EFFECTS OF VENEER DRYING AT HIGH TEMPERATURE AND CHEMICAL TREATMENTS ON EQUILIBRIUM MOISTURE CONTENT OF PLYWOOD
}

\author{
Ismail AYDIN ${ }^{I}$
}

\begin{abstract}
Moisture content (MC) is one of the most important factors that can affect many physical and mechanical properties of wood and veneers. MC strongly affects the final strength and durability of joints, development of surface checks in the wood and dimensional stability of the bonded assembly. In this study, plywood panels made from Alnus glutinosa (Alder), Fagus orientalis (Beech) and Picea orientalis (Spruce) wood veneers were treated with ammonium acetate, borax and boric acid by using dipping method to test for their equilibrium moisture content (EMC). Borax and boric acid solutions were used for fire-retardancy, and ammonium acetate for reducing formaldehyde emission. Two different veneer drying temperatures $\left(20^{\circ} \mathrm{C}\right.$ and $180^{\circ} \mathrm{C}$ ) were used to reveal the effects of veneer drying at high temperature on the hygroscopicity of plywood panels. EMC values of alder, beech and spruce panels decreased significantly with veneer drying at high temperature. Picea orientalis (Spruce) plywood panels had the highest EMC values and followed by Alnus glutinosa (Alder) and Fagus orientalis (Beech) panels. EMC values of plywood panels increased significantly for both drying temperatures after ammonium acetate, borax and boric acid treatments.
\end{abstract}

Keywords: Equilibrium moisture content, high temperature drying, impregnation, plywood.

\section{INTRODUCTION}

Plywood is a very strong and durable composite panels made from three or more wood veneers bonded together with an adhesive. In order to reduce the shrinkage and improve the strength of plywood, layers are glued together so that the wood grain in each veneer layer is perpendicular to the grain of the previous layer.

Wood and wood based materials such as veneer, plywood and lumber have a hygroscopic nature and they have the ability to release or absorb moisture to reach a moisture content that is at equilibrium with its surrounding environment. This condition is called the equilibrium moisture content (EMC). The EMC is defined as that moisture content where the wood neither gains nor looses moisture (Simpson 1999). Wood has a distinct EMC for every temperature and humidity condition, and given enough time at a constant exposure, a piece of wood will reach a given EMC. Because temperature and humidity conditions are always changing, wood is also adsorbing or desorbing moisture in response to those changing conditions. Wood rarely, if ever, reaches a true EMC condition in service, and therefore a given EMC is considered a "nominal" value (Youngquist1999). Factors that affect EMC include the specimen size, species (e.g., extractive content), and drying history (i.e., whether the sample is adsorbing or desorbing moisture). The EMC condition of wood in exterior exposure, under cover, will vary between 12 and 15\%. In an interior exposure, the EMC condition will typically vary between 5 and 8\%. Local microclimates, such as coastal conditions, can change these average values somewhat (Youngquist 1999).

\footnotetext{
Karadeniz Technical University, Faculty of Forestry, Forest Industry Engineering Department, 61080 Trabzon. Turkey

Corresponding author: iaydin@ktu.edu.tr

Received: 07.04. 2013 Accepted: 07.01. 2014
} 
The MC of wood affects the following properties: mass (weight), decay susceptibility, permeability, strength, electrical properties, heat transfer properties, adhesion, and dimensional stability (Simpson and TenWolde 1999, Green and Evans 2003, Mitchell 2004). If MC is controlled within reasonable limits, major problems from dimensional changes can usually be avoided (Simpson 1999).

The green veneers are dried to an average MC that is compatible with the adhesive system being used to bond the panels. When veneers are bonded with adhesives to make plywood, the water in adhesive mixture is absorbed by veneers. To keep the final moisture content low, the initial moisture content of the veneer should be as low as possible. However, veneer with low MC is brittle and difficult to handle without damage, so the minimum practical MC is about 4\% (Simpson 1999, Youngquist 1999). The amount of moisture in wood combined with water in adhesive will greatly influence the wetting, flow, penetration, and even cure of adhesives (Vick 1999).

Treated plywood is utilized in many applications where preservative characteristics are required, such as in concrete forming and all-weather wood foundations. Treated panels make up a large part of the plywood market (TECO 2005). Correct preservative treatment against fungal attack is essential for all plywood and LVL products, either painted or unpainted, that are permanently exposed to the weather. Infestation with termites is usually not a problem for plywood and LVL provided the application does not involve ground contact and other good building practices have been correctly implemented through appropriate design and construction practices as well as ongoing inspection and maintenance (EWPAA 2014).

One of the most important stage in the manufacturing of wood based panel products such as plywood and laminated veneer lumber (LVL) is veneer drying. Drying process accounts for some 70 percent of the thermal energy consumed in plywood production and approximately 60 percent of the mill's total energy requirement. Although drying temperatures of between $90-160^{\circ} \mathrm{C}$ may be considered normal, increased temperatures are being used to reduce the overall drying time and increase capacity (FAO 1990). Reductions in drying time and energy consumption offer the wood industries a great potential for economic benefit (Rice 1988).

Borax and boric acid solutions are used for fire-retardancy. The fire-retardancy of boron compounds has been noted (LeVan and Tran 1990), besides their having a well-established record of performance against a broad spectrum of wood destroying organisms such as termites, decay fungi, beetles and carpenter ants (Reeb 1997, Lebow 2000). On the other hand, some studies have indicated that when wood treated with ammonium acetate solution, the formaldehyde emission from the wood composites reduced (Çolak et al. 2002, Myers 1986). It was stated that the ammonium acetate behaves as a formaldehyde scavenger especially when urea-formaldehyde glue were used as adhesive in the manufacturing of wood composites (Aydin 2004). The objective of this study was to determine the influence of high temperature veneer drying and preservative treatments with boron compounds and ammonium acetate solutions applied to the individual veneer sheets on the EMC of Alder, Beech and Spruce plywood panels.

\section{MATERIAL AND METHODS}

Alder (Alnus glutinosa subsp. barbata), Beech (Fagus orientalis Lipsky) and Spruce (Picea orientalis L.) logs with average diameters at breast height of 30, 45 and $40 \mathrm{~cm}$, respectively, were harvested from Trabzon Region/Turkey for veneers. Logs were debarked and bucked into $60 \mathrm{~cm}$ lengths. Beech and spruce $\operatorname{logs}$ were steamed at a temperature of $80^{\circ} \mathrm{C}$ for 20 and 12 hours, respectively, before veneer peeling while the alder logs were peeled fresh. Veneer sheets with dimensions of $50 \mathrm{~cm}$ by $50 \mathrm{~cm}$ by $2 \mathrm{~mm}$ were clipped by using a rotary peeler. Vertical opening was $0.5 \mathrm{~mm}$ and horizontal opening was $85 \%$ of the veneer thickness in veneer manufacturing process. 
After peeling, veneer sheets were air-dried at $20^{\circ} \mathrm{C}$ or in a veneer dryer at $180^{\circ} \mathrm{C}$ for $5 \mathrm{~min}$. Some of the dried veneers $\left(20^{\circ} \mathrm{C}\right.$ or $\left.180^{\circ} \mathrm{C}\right)$ for each wood species were immersed in solutions of $5 \%$ borax $\left(\mathrm{Na}_{2} \mathrm{~B}_{4} \mathrm{O}_{7} 10 \mathrm{H}_{2} \mathrm{O}\right)$, boric acid $\left(\mathrm{H}_{3} \mathrm{BO}_{3}\right)$ or ammonium acetate $\left(\mathrm{CH}_{3} \mathrm{COONH}_{4}\right)$ for $20 \mathrm{~min}$. Before treatments, veneers were conditioned in a conditioning chamber to approximately $7 \% \mathrm{MC}$ and all treated veneers were re-dried at $100^{\circ} \mathrm{C}$ after treatments. Experimental design of test groups based on wood species, veneer drying temperature and type of preservative treatment are presented in table 1, and the retention for each treatment solution are presented in table 2 .

Table 1. Experimental design of test groups based on wood species, veneer drying temperature and type of preservative treatment.

\begin{tabular}{|c|c|c|c|c|c|c|c|}
\hline & \multicolumn{6}{|c|}{ Wood Species } \\
\hline & & \multicolumn{2}{|c|}{$\begin{array}{l}\text { Alnus glutinosa } \\
\text { (Alder) }\end{array}$} & \multicolumn{2}{|c|}{$\begin{array}{c}\text { Fagus } \\
\text { orientalis } \\
\text { (Beech) }\end{array}$} & \multicolumn{2}{|c|}{$\begin{array}{c}\text { Picea } \\
\text { orientalis } \\
\text { (Spruce) }\end{array}$} \\
\hline Veneer Dr & ing Temperature & $20^{\circ} \mathrm{C}$ & $180^{\circ} \mathrm{C}$ & $20^{\circ} \mathrm{C}$ & $180^{\circ} \mathrm{C}$ & $20^{\circ} \mathrm{C}$ & $180^{\circ} \mathrm{C}$ \\
\hline \multirow{4}{*}{$\begin{array}{l}\text { Treatment } \\
\text { Type }\end{array}$} & Untreated control & A1 & $\mathrm{A} 2$ & B1 & B2 & S1 & S2 \\
\hline & $\begin{array}{l}\text { Ammonium } \\
\text { acetate }\end{array}$ & A1AA & A2AA & B1AA & B2AA & S1AA & S2AA \\
\hline & Borax & A1B & A2B & B1B & $\mathrm{B} 2 \mathrm{~B}$ & S1B & S2B \\
\hline & Boric acid & A1BA & A2BA & B1BA & B2BA & S1BA & S2BA \\
\hline
\end{tabular}

Table 2. Retentions of ammonium acetate, borax and boric acid solutions based on wood species and veneer drying temperature (values in parenthesis are standard deviations).

\begin{tabular}{|c|c|c|c|c|c|}
\hline $\begin{array}{c}\text { Almus } \\
\text { glutinosa } \\
\text { (Alder) } \\
\text { Groups }\end{array}$ & $\begin{array}{c}\text { Retention } \\
\left(\mathrm{kg} / \mathrm{m}^{3}\right)\end{array}$ & $\begin{array}{c}\text { Fagus } \\
\text { orientalis } \\
\text { (Beech) } \\
\text { Groups }\end{array}$ & $\begin{array}{l}\text { Retention } \\
\left(\mathrm{kg} / \mathrm{m}^{3}\right)\end{array}$ & $\begin{array}{c}\text { Picea } \\
\text { orientalis } \\
\text { (Spruce) } \\
\text { Groups }\end{array}$ & $\begin{array}{l}\text { Retention } \\
\left(\mathrm{kg} / \mathrm{m}^{3}\right)\end{array}$ \\
\hline A1AA & $\begin{array}{l}11,35 \\
(1,04)\end{array}$ & B1AA & $\begin{array}{l}16,93 \\
(1,13)\end{array}$ & S1AA & $\begin{array}{l}11,35 \\
(0,67)\end{array}$ \\
\hline A1B & $\begin{array}{c}9,78 \\
(1,16)\end{array}$ & B1B & $\begin{array}{l}15,38 \\
(0,80)\end{array}$ & S1B & $\begin{array}{c}9,43 \\
(1,03)\end{array}$ \\
\hline A1BA & $\begin{array}{l}10,02 \\
(0,72)\end{array}$ & B1BA & $\begin{array}{l}16,55 \\
(1,31)\end{array}$ & S1BA & $\begin{array}{c}9,75 \\
(2,11)\end{array}$ \\
\hline $\mathrm{A} 2 \mathrm{AA}$ & $\begin{array}{l}10,91 \\
(0,54)\end{array}$ & B2AA & $\begin{array}{l}15,78 \\
(1,16)\end{array}$ & S2AA & $\begin{array}{l}11,05 \\
(0,86)\end{array}$ \\
\hline A2B & $\begin{array}{c}9,35 \\
(0,79)\end{array}$ & B2B & $\begin{array}{l}13,62 \\
(2,41)\end{array}$ & S2B & $\begin{array}{c}9,20 \\
(0,94)\end{array}$ \\
\hline $\mathrm{A} 2 \mathrm{BA}$ & $\begin{array}{l}10,86 \\
(0,69)\end{array}$ & B2BA & $\begin{array}{l}14,92 \\
(1,37)\end{array}$ & S2BA & $\begin{array}{c}9,90 \\
(0,95)\end{array}$ \\
\hline
\end{tabular}

Two replicate plywood panels with three layers and $6 \mathrm{~mm}$ thickness were manufactured for all test groups indicated in table 1, by using urea-formaldehyde (UF) resin. Before gluing process, veneers were conditioned to approximately $7 \% \mathrm{MC}$ in a conditioning chamber. The resin mix was composed of 100 parts UF resin (55\% solid content), 30 parts wheat flour and 10 parts hardener $\left(15 \% \mathrm{NH}_{4} \mathrm{Cl}\right)$ by weight. Approximately $160 \mathrm{~g} / \mathrm{m}^{2}$ resin was spread on single surfaces of veneers by a four roller gluing machine. Hot press pressure was $12 \mathrm{~kg} / \mathrm{cm}^{2}$ for Alnus glutinosa (Alder) and Fagus orientalis (Beech) and $8 \mathrm{~kg} / \mathrm{cm}^{2}$ for Picea orientalis (Spruce) panels while pressing time and temperature were 5 min and $110^{\circ} \mathrm{C}$, respectively. 
Test specimens for the determination of EMC values of plywood panels were prepared according to EN 322 standard. This standard specifies an oven dry method for determining MC of wood-based panels. Thirty specimens for all test groups $(50 \mathrm{~mm} \times 50 \mathrm{~mm} \times 6 \mathrm{~mm})$ were used to evaluate the effects of veneer drying temperature and treatment on the hygroscopicity of plywood panels.

\section{RESULTS AND DISCUSSION}

Effect of veneer drying temperature on EMC is shown in figure 1. Average EMC values of Alnus glutinosa (Alder), Fagus orientalis (Beech) and Picea orientalis (Spruce) panels before and after treatments with ammonium acetate, borax and boric acid are shown respectively in figures 2, 3 and 4 .

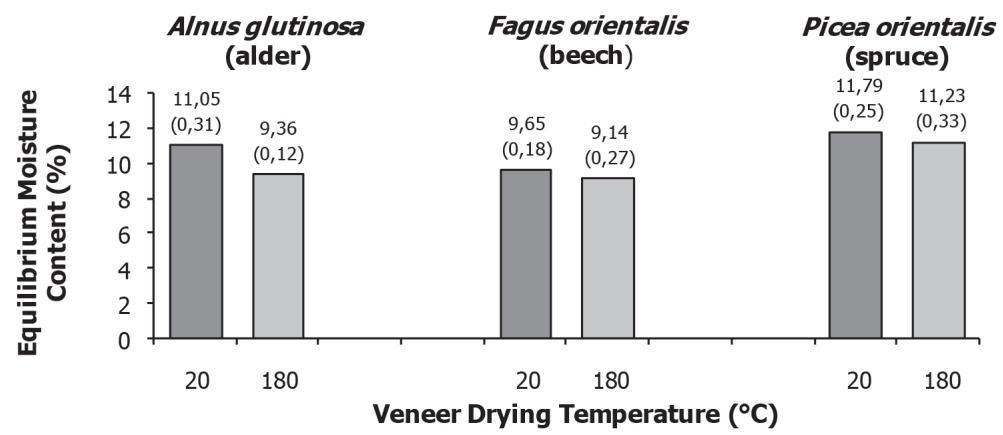

Figure 1. Effect of veneer drying temperature on EMC of Alnus glutinosa (Alder), Fagus orientalis (Beech) and Picea orientalis (Spruce) plywood panels (values in parenthesis are standard deviations).

Multifactor analysis of variance was performed for statistical evaluation of the variations in EMC values depending on wood species, veneer drying temperature and treatment type. Student-Newman-Keuls test was used to compare the average values of variance sources with $95 \%$ confidence level. Results for statistical evaluation are summarized in table 3.

Table 3. Results of Student-Newman-Keuls test at 95\% confidence level.

\begin{tabular}{lcc}
\hline \multicolumn{1}{c}{ Factors } & $\begin{array}{c}\text { LS } \\
\text { Mean }\end{array}$ & $\begin{array}{c}\text { Homogenous } \\
\text { Groups* }\end{array}$ \\
\hline Wood Species & & \\
Alnus glutinosa (Alder) & 11,10 & $\mathrm{a}$ \\
Fagus orientalis (Beech) & 10,59 & $\mathrm{~b}$ \\
Picea orientalis (Spruce) & 12,02 & $\mathrm{c}$ \\
\hline Veneer Drying Temp. & 11,53 & \\
$20^{\circ} \mathrm{C}$ & 10,94 & $\mathrm{a}$ \\
$180^{\circ} \mathrm{C}$ & & $\mathrm{b}$ \\
\hline Treatment Type & 10,37 & $\mathrm{a}$ \\
Untreated control & 11,20 & $\mathrm{~b}$ \\
Ammonium acetate & 11,65 & $\mathrm{c}$ \\
Borax & 11,74 & $\mathrm{c}$ \\
Boric acid &
\end{tabular}

* Different letters denote a statistically significant difference 
Figure 1 and table 3 showed that the EMC values of Alder, Beech and Spruce panels decreased significantly with high temperature veneer drying. Spruce plywood panels had the highest EMC values followed by Alder and Beech panels. The highest average EMC value (11,79\%) was obtained for spruce plywood panels manufactured from veneers dried at $20^{\circ} \mathrm{C}$, while beech panels manufactured from veneers dried at $180^{\circ} \mathrm{C}$ had the lowest average EMC value $(9,14 \%)$. After drying at high temperature $\left(180^{\circ} \mathrm{C}\right)$, a decrease of 15,3\% for Alder panels, 5,3\% for Beech panels and 4,8\% for Spruce panels in EMC was occurred, as can be seen from figure 1. When wood dried at high temperatures, the hemicelluloses of wood decompose and the number of reactive hydroxyl groups diminishes. Diminished hydroxyl groups may cause a decrease in EMC (Lehtinen 1998). In a study carried out by Lee and Roffael (1989) to determine the influence of drying on the EMC of particles and particleboards from pinewood, severe-dried flakes showed lower EMC than mild-or moderate-dried flakes.

Hot-pressed plywood and other board products usually do not have the same MC as lumber. The high temperatures used in hot presses cause these products to assume a lower MC for a given relative humidity. Because this lower EMC varies widely, depending on the specific type of hot-pressed product, it is recommended that such products be conditioned at 30\% to $40 \%$ relative humidity for interior use and $65 \%$ for exterior use (Simpson 1999).

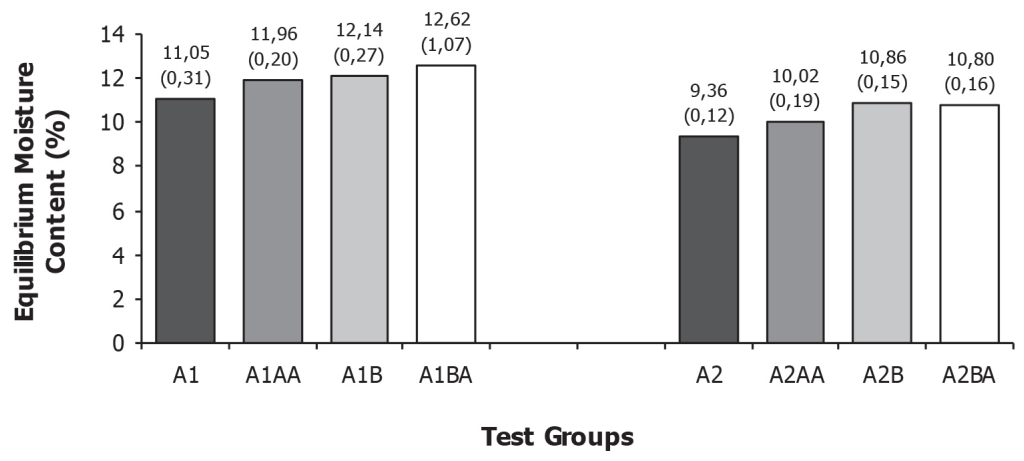

Figure 2. Effect of ammonium acetate, borax and boric acid treatments on EMC of Alnus glutinosa (Alder) plywood panels (values in parenthesis are standard deviations).

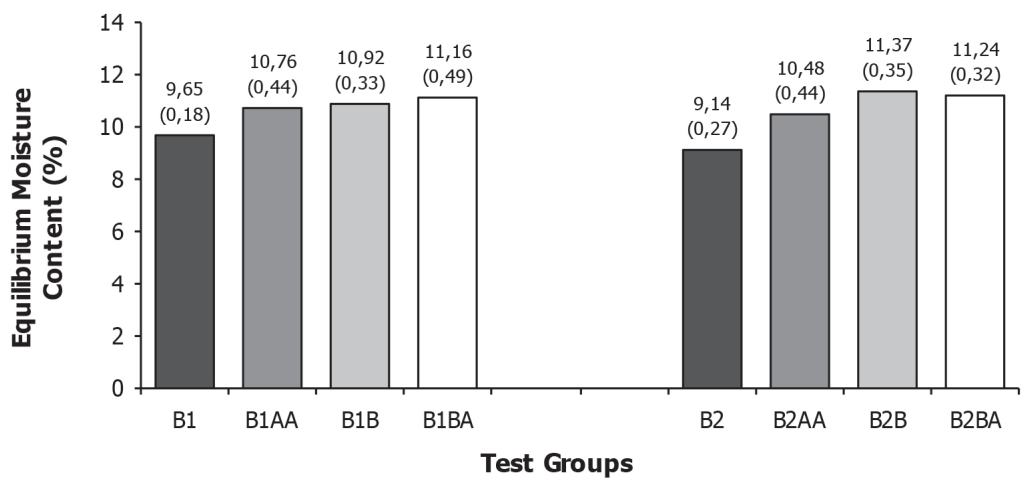

Figure 3. Effect of ammonium acetate, borax and boric acid treatments on EMC of Fagus orientalis (Beech) plywood panels (values in parenthesis are standard deviations). 


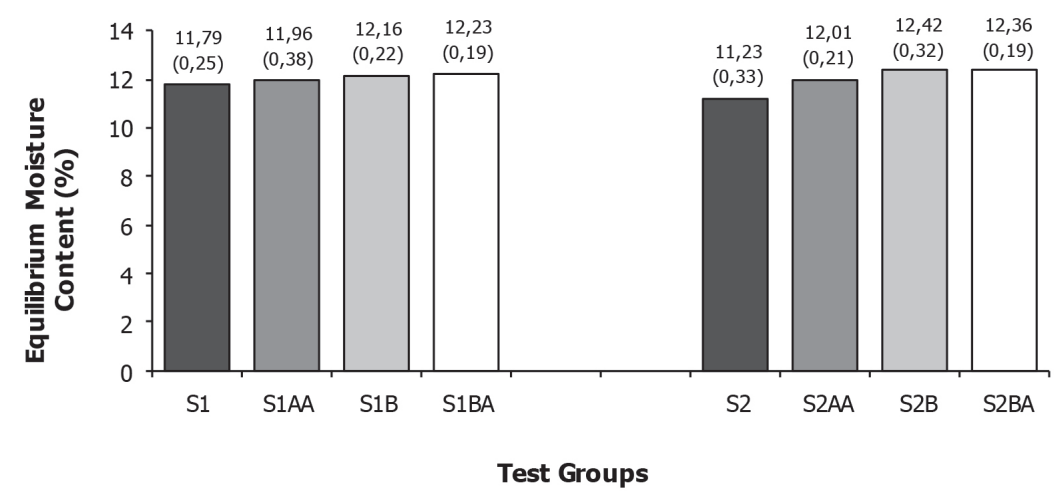

Figure 4. Effect of ammonium acetate, borax and boric acid treatments on EMC of Picea orientalis (Spruce) plywood panels (values in parenthesis are standard deviations).

As shown in figures 2, 3 4, the EMC values of plywood panels increased for both drying temperatures after ammonium acetate, borax and boric acid treatments. These increases were found statistically significant (Table 3). However, there were no significant changes in EMC values of the panels manufactured from veneers treated with borax and boric acid. The lowest EMC in Alder, Beech and Spruce plywood panels were obtained for untreated control, while the highest values were obtained for panels manufactured from boric acid-treated veneers for air-dried groups and borax-treated veneers for oven-dried groups (Figures 2, 3 and 4). This phenomenon is consistent with the literature, because of the high hygroscopicity of some of the fire-retardant chemicals. The hygroscopicity of wood treated with inorganic fire retardants are usually greater than that of untreated wood and this depends on wood size, species of wood, temperature, relative humidity, and the type and amounts of chemicals used (Holmes 1997, White and Dietenberger 1999, Winandy et al. 1988). An increase in EMC at high relative humidity has been a major problem in the use of fire retardant-treated lumber and plywood. This is particularly true at the higher relative humidity conditions. This higher hygroscopicity may cause staining, decay, poor paint adhesion, migration and exuding of chemicals and moisture at the high humidities. Some fire retardants absorb excessive moisture which can create problems with appearance, surface finishing, and corrosion of metal fasteners (Winandy et al. 1988). The unstable EMC can be observed at excessive joint swelling and shrinkage under changing conditions (Winandy et al. 1988). 


\section{CONCLUSIONS}

High temperature veneer drying caused a significant decrease in EMC values of Alnus glutinosa (Alder), Fagus orientalis (Beech) and Picea orientalis (Spruce) panels. When compared to air-dried plywood groups, lower EMC values were obtained after veneer drying at high temperature $\left(180^{\circ} \mathrm{C}\right)$. Picea orientalis (Spruce) plywood panels had the highest EMC values and followed by Alnus glutinosa (Alder) and Fagus orientalis (Beech) panels.

The EMC of plywood panels increased after ammonium acetate, borax and boric acid treatments. The lowest EMC in Alnus glutinosa (Alder), Fagus orientalis (Beech) and Picea orientalis (Spruce) plywood panels were obtained for untreated (control) groups, while the highest values were obtained for panels manufactured from boric acid-treated veneers for air-dried groups and borax-treated veneers for ovendried groups.

It can be concluded that treatment with boron compounds and ammonium acetate had an increasing effect in equilibrium moisture content of plywood panels. Therefore, designers and users of plywood panels should take into account these physical properties when they use treated-plywood panels at different usage areas. It is also recommended that panels having extreme MC (too low or too high) should be conditioned at proper relative humidity before the applications.

\section{REFERENCES}

Aydin, I. 2004. Effects of some manufacturing conditions on wettability and bonding of veneers obtained from various wood species. Ph.D. thesis, Graduate School of Natural and Applied Sciences, Karadeniz Technical University, Trabzon, Turkey.

Colak, S.; Colakoglu, G.; Testereci, H.; Aydin, I. 2002. Formaldehyde and volatile acetic acid emission of plywood treated with ammonium acetate. Paper presented at the sixth european panel products symposium, North Wales Conference Centre, Llandudno, North Wales, UK.

European Standardisation Committee. EN. 1993. Wood-based panels- Determination of moisture content. EN 322. Brussell.

Engineered Wood Products Association of Australasia. EWPAA. 2014. Plywood and LVL Tutorials - Preservative Treatment.

[online]<http://www.ewp.asn.au/library/tut_ply/finishespreservative.html>[accesed 21.03.2013]

Food and Agriculture Organization of The United Nations. FAO. 1990. Energy conservation in the mechanical forest industries: FAO Forestry Paper, Rome, 118 p.

Green, D.W.; Evans, J.W. 2003. Effect of low relative humidity on properties of structural lumber products. Wood and Fiber Science 35(2):247-265.

Holmes, C.A. 1997. Effect of fire-retardant treatments on performance properties of wood. U.S.D.A. Forest Service, Research Note FPL-0167, Forest Products Laboratory, Madison, WI.

Lebow, S. 2000. What's in that pressure-treated wood. Techline, Issue 07, U.S., Department of Agriculture, Forest Service, Forest Products Laboratory, 3 p.

Lee, C.L.; Roffael, E. 1989. Influence of drying on the equilibrium moisture content (EMC) of particles and particleboards from pinewood. Holz als Roh- und Werkstoff 47(7): 267-271. 
Lehtinen, M. 1998. Effects of manufacturing temperatures on the properties of plywood. Helsinki University of Technology, Laboratory of Structural Engineering and Building Physics. TRT Report No 92, Finland.

Levan, S.L.; Tran, H.C. 1990. The role of boron in flame-retardant treatments. Paper presented at the first international conference on wood protection with diffusible preservatives, Forest Products Research Society, Nashville, TN. Madison, WI.

Mitchell, P. 2004. Methods of moisture content measurement in the lumber and furniture industries. Wood products notes. Department of Wood and Paper Science, College of Forest Resources, North Carolina State University

Myers, G.E. 1986. Effects of post-manufacture board treatments on formaldehyde emission: A literature review (1960-1984). Forest Products Journal 36(6):41-45.

Reeb, J.E. 1997. Wood-destroying organisms \& wood preservatives. Cooperative extension service, FOR-54, University of Kentucky, College of Agriculture, 8 p.

Rice, R.W. 1988. Mass transfer, creep and stress development during the drying of red oak. Ph.D. dissertation, Virginia Polytechnique Institute and State University, Blacksburg, Virginia, USA.

Simpson, W.T. 1999. Drying and control of moisture content and dimensional changes. In: Wood handbook-Wood as an engineering material, Gen. Tech. Rep. FPL-GTR-113, Chapter 12, Madison, WI: U.S. Department of Agriculture, Forest Service, Forest Products Laboratory, 463 p.

Simpson, W.; Tenwolde, A. 1999. Physical properties and moisture relations of wood. In: Wood handbook-Wood as an engineering material, Gen. Tech. Rep. FPL-GTR-113, Chapter 3, Madison, WI: U.S. Department of Agriculture, Forest Service, Forest Products Laboratory, 463 p.

TECO. 2005. Structural Plywood - Design and Application Guide. TECO wood products certification and testing,

[online]<http://www.tecotested.com/techtips/pdf/plywooddesignapplicationguide> [accesed 02.03.2013]

Vick, C.B. 1999. Adhesive bonding of wood materials. In: Wood handbook-Wood as an engineering material, Gen. Tech. Rep. FPL-GTR-113, Chapter 9, Madison, WI: U.S. Department of Agriculture, Forest Service, Forest Products Laboratory, 463 p.

White, R.H.; Dietenberger, M.A. 1999. Fire safety. In: Wood Handbook. Chapter 17, Gen. Tech. Rep. FPL-GTR-113. Madison, WI: U.S.D.A. Forest Service, Forest Products Laboratory.

Winandy, J.E.; Levan, S.L.; Schaffer, E.L.; Lee, P.W. 1988. Effect of fire-retardant treatment and redrying on the mechanical properties of douglas-fir and aspen plywood. Research paper, FPL-RP-485, Forest Service, Forest Products Laboratory, U.S. Department of Agriculture, Madison, WI, 20 p.

Youngquist, J.A. 1999. Wood-based Composites and Panel Products. In: Wood handbook-Wood as an engineering material, Gen. Tech. Rep. FPL-GTR-113, Chapter 10, Madison, WI: U.S. Department of Agriculture, Forest Service, Forest Products Laboratory, 463 p. 